\title{
Curcumin Analog Pentagamaboronon-0-Sorbitol Inhibits Cell Migration Activity of Triple Negative Breast Cancer Cell Line
}

\author{
Ratna Dwi Ramadani ${ }^{1}$, Rohmad Yudi Utomo ${ }^{2}$, Adam Hermawan ${ }^{2,3}$, Edy Meiyanto Ed, $^{2,3}$ \\ 'Magister Program of Biotechnology, Faculty of Pharmacy, Universitas Gadjah Mada, Yogyakarta, Indonesia \\ ${ }^{2}$ Cancer Chemoprevention Research Center, Faculty of Pharmacy, Universitas Gadjah Mada, Yogyakarta, Indonesia \\ ${ }^{3}$ Departement of Pharmaceutical Chemistry, Faculty of Pharmacy, Universitas Gadjah Mada, Yogyakarta, Indonesia
}

\begin{abstract}
Mortality in cancer is primarily due to failure of metastasis prevention. One strategy to target the cancerous cell is Boron Neutron Captured Therapy which showed high affinity toward cancer cells and reported to have anti-proliferative as well as antimetastatic activities. Cancer Chemoprevention Research Center Faculty of Pharmacy Universitas Gadjah Mada, has developed boron-containing substance namely pentagamaboronon-0 (PGB-0) which is known to exhibit anticancer activity towards breast cancer cell. The purposes of this research are focused to explore the anti-migratory activities of PGB-0-So against triple negative breast cancer cell. The MTT cytotoxicity assay of PGB-0-So against 4T1 breast cancer cell line were found to exert potential effect in dose-dependent manner with IC50 values of $39 \mu \mathrm{M}$. The study of cell migration inhibition using in vitro wound healing assays and gelatin zymography on highly metastasis breast cancer cell line 4T1, following the treatment of sub IC50 doses of PGB-0-So complex slightly inhibited cell migration through the inhibition of matrix metalloproteinase- 9 expression. These findings suggest that PGB-0-So is potential as an anticancer agent.
\end{abstract}

Keywords : curcumin analogue, PGB-0-So, 4T1 Cells, migration, MMP-9

\section{INTRODUCTION}

Breast cancer is the most common type of cancer causing mortality for women. In 2012, there were registered 1.67 million new cases of breast cancer mortality in women by 198,000 (Ferlay, et al., 2012). It was estimated that approximately $10-15 \%$ of breast cancer was known to be triple negative breast cancer (TNBC) (Dawood, 2010). This breast cancer subtype is positive-metastatic breast cancer (MBC) which have worse prognosis leading to aggressive disease. Moreover, failure of metastasis prevention primarily caused mortality in breast cancer.
The treatment of metastasis in breast cancer was conducted by chemotherapy, such as doxorubicin which performed strong cytotoxicity against cancer cells. Despite its potent anticancer activity, doxorubicin had several limitations for long-term use including cardiotoxicity and chemoresistance (Carvalho, et al., 2009; Thorn, et al., 2011). In addition, low dose of doxorubicin induces

Submitted: July 27, 2018

Revised: September 4, 2018

Accepted: September 7, 2018

*Corresponding author: edy_meiyanto@ugm.ac.id 
epithelial-mesenchymal transition (EMT) leading to metastasis on breast cancer cells (MBC) (Bandyopadhyay, et al., 2010). Hence, several antimetastatic agents had been developed to treat MBC.

Development of anti-metastatic agents as potential candidate of chemotherapeutic agents has been established over the years. Patients characterized as triple negative breast cancer are treated with taxanes or platinum compounds (Gavilá, et al., 2015). Similar to doxorubicin, taxanes in low dose induced peripheral neuropathy in breast cancer (Bhatnagar, et al., 2014), while platinum compound (cisplatin) induced EMT in ovarian cancer (Baribeau, et al., 2014). Thus, the effective anti-metastatic agents need to be developed further.

Curcumin analogues based on benzylidine cyclopentanonebackbonesuchasPentagamavunon-0 (PGV-0) and Pentagamavunon-1 (PGV-1) exert potent cytotoxic (Meiyanto, et al. (2006); Nurulita, et al. (2006); Dai, et al. (2007); Dai, et al. (2011); Hermawan, et al. (2011); Meiyanto, et al. (2014) and anti-metastatic activities toward several types of breast cancer cells (Putri, et al., 2016). Pentagamaboronon-0 (PGB-0) is a novel curcumin analogue based on benzylidine cyclopentanone developed by Faculty of Pharmacy Universitas Gadjah Mada. Cytotoxicity of PGB-0 toward HER2 positive breast cancer had been determined and showed to decrease HER2 expression (Utomo, et al., 2017). PGB-0 also performed anti-metastatic activity toward triple negative breast cancer cells (unpublished data). However, similar to curcumin, PGB-0 is less soluble in water. To improve solubility of PGB-0, we synthesized the complex form of PGB-0 with polyol sugar, sorbitol, namely PGB-0So.

This study aims to develop PGB-0-So as novel anti-cancer agent especially through the inhibition of cell migration. 4T1 cells were used as a model of highly metastatic breast cancer cell line. Possible anti-metastasis activities of PGB-0-So were analyzed by using scratch wound healing assay and gelatin zymography. The result of this study will be used for further experiment in order to develop novel anti-migratory agents from PGB-0-So.

\section{MATERIALS AND METHODS}

\section{Chemicals}

PGB-0-So was synthesized by Cancer Chemoprevention Research Center, Faculty of Pharmacy, Universitas Gadjah Mada. Doxorubicin was purchased from Sigma.

\section{Cell Culture}

4T1 breast cancer cells were obtained from Prof. Masashi Kawaichi, M.D., Ph.D (Nara Institute of Science and Technology, NAIST, Japan). The cells were maintained in Dulbecco's Modified Eagles Medium (DMEM) high glucose (Sigma, St. Louis, CA, USA) with 10\% FBS (Sigma), HEPES, sodium bicarbonate, $1000 \mathrm{U} / \mathrm{mL}$ of Penicilin- 1000 $\mathrm{U} / \mathrm{ml}$ of Streptomycin and $0.5 \mu \mathrm{g} / \mathrm{mL}$ Fungizone (Gibco, New York, USA).

\section{Scratch Wound Healing Assay}

The 4T1 breast cancer cells were seeded $7.5 \times 10^{4}$ cells per well in 24 well-plate. Cells were incubated for 24 hours until $80 \%$ confluent. Media was removed and well was washed with $100 \mu \mathrm{L}$ PBS (Sigma). Then cells were added with media contained $0.5 \%$ FBS for starvation and incubated for 22 hours. Each well was scratched vertically by using yellow tip and treated with Doxorubicin 10 $\mathrm{nM}$ as positive control, PGB- $0-\mathrm{F}$, and combination of both compounds. The closures of cell migration were observed in $0,18,24$ and 42 hours under inverted microscope (Olympus, Tokyo, Japan) and captured by Handphone (Samsung, Seoul, South Korea).

\section{Gelatin-Zymography Methods}

A total of $2 \times 10^{5} 4 \mathrm{~T} 1$ cells were planted in a 6-well plate with $2 \mathrm{~mL}$ of culture medium and incubated for 24 hours. The samples solution was carried out using culture medium containing 
$0.5 \%$ FBS. After incubation, the media is removed and washed with PBS $1 \mathrm{~mL} 1$ times. Cell then treated with various concentration of PGB-0-So and doxorubicin. Estradiol was used to induce the expression of MMP-9. The cells then were incubated again for 48 hours. Culture medium then collected in $1.5 \mathrm{~mL}$ microtube and centrifuged at $4^{\circ} \mathrm{C}$ and then take the supernatant. The sample has been obtained by loading the buffer and running in appropriate concentration electrophoresis. Gel that has gelatin mold. The checking process with electrophoresis $(\mathrm{V}=120 \mathrm{~V}, \mathrm{I}=60 \mathrm{~A})$ was carried out for 130 minutes. After that, the gel is done and renaturation using a renaturing solution containing Triton-X 100 to remove SDS for 30 minutes. Continued with incubation for $20 \mathrm{~h}$ using an incubation solution at $37^{\circ} \mathrm{C}$. Then, it should be stained with coomasie brilliant blue for 30 minutes, and through destaining using a destaining solution until the transparent blue band appears.

\section{Data Analysis}

Scratch wound healing analysis was figured out by measuring the distance between scratch edges using ImageJ software then comparing the untreated and treated cells. Data from multiple scratch within the same test group were analyzed using Analysis of Variance test to analyze the difference between experimental group. Data were presented as mean \pm S.D and analyzed by oneway ANOVA. $p<0.05$ was considered statistically significant.

\section{RESULTS AND DISCUSSION}

\section{Anti-migratory Effect of PGB-0-So and Its Combination with Doxorubicin against 4T1 cell}

The purpose of this study is to develop a novel anti-cancer agent which especially plays role in inhibiting cancer cell migration. In this study, we used highly metastatic breast cancer cell model, 4T1, to explore the potency of PGB-0-So in inhibiting cell migration. Low concentration of Doxorubicin (Dox) in this study was used to induce migration (Bandyopadhyay, et al., 2010). Scratch wound healing assay was conducted to observe cells migration following the treatment of several concentrations under IC50 value of $1 / 8,1 / 4$, and $1 / 2$ of $\mathrm{IC}_{50}$, which are nontoxic and appropriate concentration to observe cell migration activity. The $\mathrm{IC}_{50}$ value of PGB-0-So against $4 \mathrm{~T} 1$ cell was 40 $\mu \mathrm{M}$. After 42 hours observation, Dox increased the $\%$ closure up to $100 \%$ indicating the cell migration activity. On the other hand, single treatment of $1 / 2 \quad \mathrm{IC}_{50}$ PGB-0-So $(20 \mu \mathrm{M})$ showed significant inhibitory activity against 4T1 cell line whereas the concentrations of $1 / 4$ and $1 / 8 \mathrm{IC}_{50}$ value (10 and 5 $\mu \mathrm{M})$ of PGB-0-So showed unsignificant inhibitory anti-migratory activity compared to the untreated group. Interestingly, combination of Dox with all concentrations of PGB-0-So showed significant anti-migratory activity against doxorubicin-induced 4T1 cell (Figure 1). The result needs to be confirmed with the expression of certain protein played role on cells migration or invasion.

\section{Effect of PGB-0-So and Its Combination with Doxorubicin against MMP-9 Expression}

Secondary Cancer cells migration and invasion was tightly regulated by certain proteins especially Matrix Metalloproteinase 9 (MMP-9). Role of MMP-9 on cells migration and invasion was to degrade extracellular matrix (ECM) around cancer cells (Yabluchanskiy, et al., 2013; Reunanen, et al., 2013). To observe possible effect of PGB-0-So on the decreasing expression of MMP-9, gelatine zymography was performed. Low concentration of Dox $(10 \mathrm{nM})$ showed decreased expression of MMP-9 expression indicating the different possible effector of anti-migratory activity might be induced by Dox. Amalina, et al. (2017) reported that low dose of Dox induced EMT through Rac1 independent-lamellipodia formation by which the initial progression of cancer cell migration. In contrast, both single treatment of PGB-0-So and 
Ramadani, et al, 2018

Indones. J. Cancer Chemoprevent., 9(3), 126-133

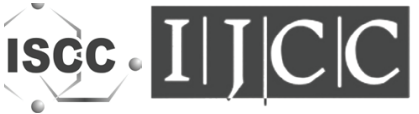

A

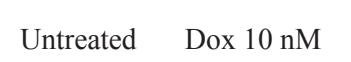

PGB-0-So

PGB-0-So

PGB-0-So

PGB-0-So

PGB-0-So

PGB-0-So
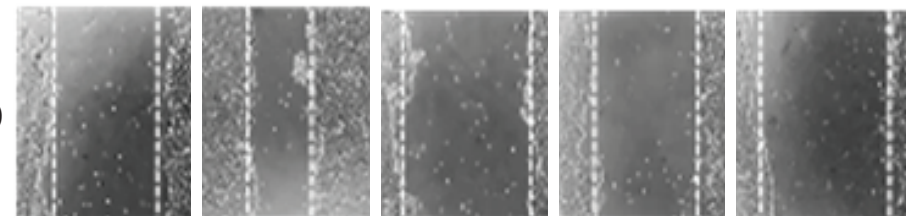

$20 \mu \mathrm{M}+$ Dox
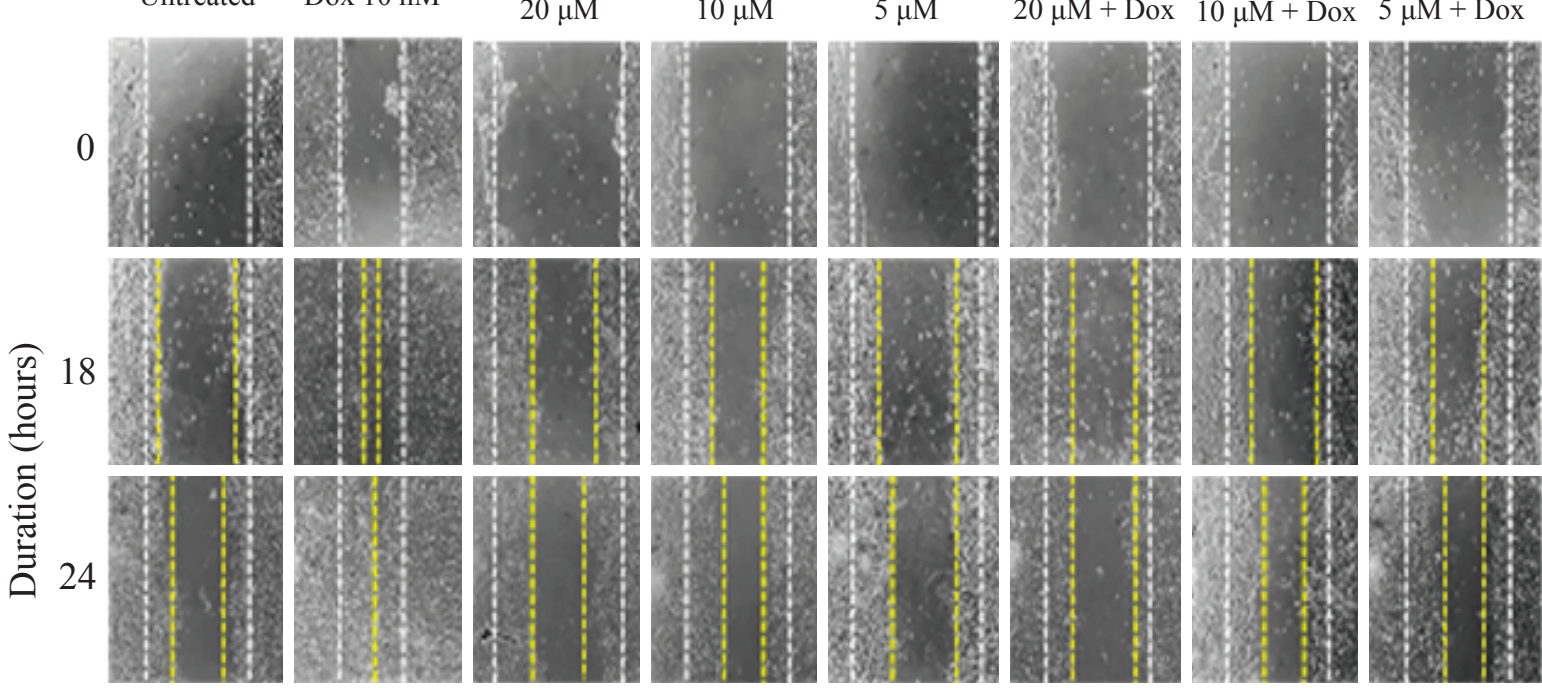

42
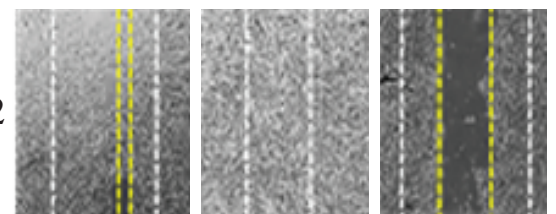

B

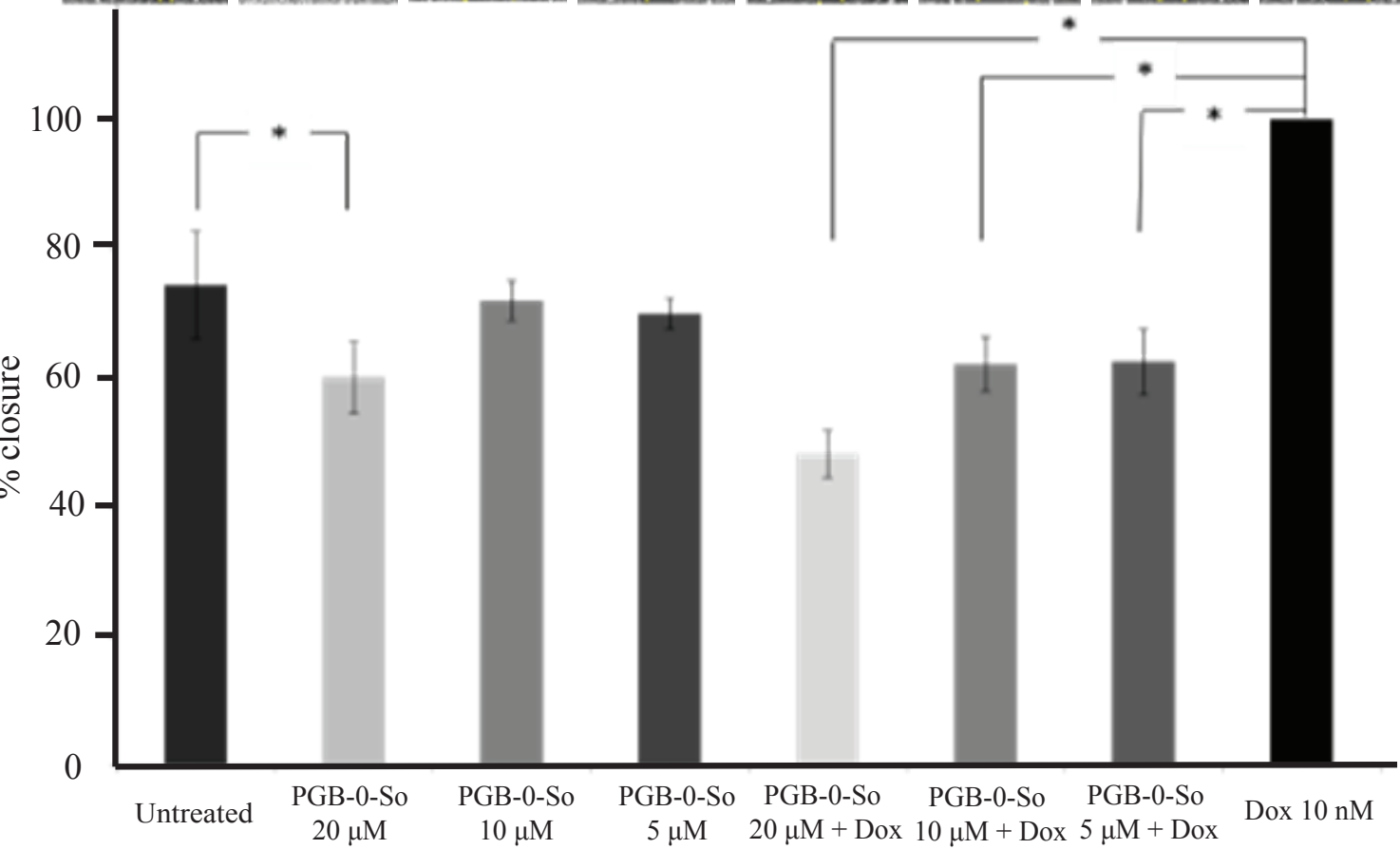

Figure 1. Anti-migratory Effect of PGB-0-So against Highly Metastatic, 4T1, Cells Migration. 4T1 cells $\left(7.5 \times 10^{4}\right.$ cells/well) were treated with PGB-O-F in the concentration as indicated in the figure, then subjected for scratch wound healing assay. A: The morphology of the cells after scratch and treated with PGB-0-So. Observations were made after 18,24 and 42 hour of treatment under an inverted microscope with magnification of 100x. B: The percentage of $4 \mathrm{~T} 1$ cells closure after treatment. The area of the scratch were analyzed using ImageJ software then \% closure was calculated in accordance with the procedures of the analysis $(p<0.05)$. 
its combination with Dox showed the decreasing expression of MMP-9 protein in dose dependent manner (Figure 2). Hence, anti-migratory effect of PGB-0-So against 4T1 cell might be through the suppression of MMP-9 expression.

\section{DISCUSSION}

Inhibition of tumor cell migration is crucial in the therapy and inhibition of cancer spread, especially in metastasis. Thus, it is necessary to develop anti-migratory agent to overcome this situation. Previous research showed that PGB0 exhibited anti-migratory effect as well as inhibited MMP-9 expression (unpublished data). MMP-9 is a family member of zinc- and calciumdependent endopeptidases, $88 \mathrm{kDa}$ protein which has numerous cell activities, involving in various physiological functions, such as cell-cell contact, tissue remodeling cell migration and cellular differentiation (Yabluchanskiy, et al., 2013; Vandooren, et al., 2013).

Other study using boron containing compound, phenylboronic acid showed that this compound has potency as selective inhibitor of cancer cell migration and viability without effecting non-tumorigenic cell lines (Bradke, et al., 2008; McAuley, et al., 2011). The main purpose of this study is to explore the potential metastasis-inhibitory of PGB-0-So on triple negative breast cancer cells, 4T1. In this study, $4 \mathrm{~T} 1$ cells were used as the model of human metastatic breast cancer cells because it is highly metastatic breast cancer cells. This cells can metastasize to liver, lung, bone and brain, making it a good model of human metastatic breast cancer (Pulaski, et al., 2000; DuPré, et al., 2007).

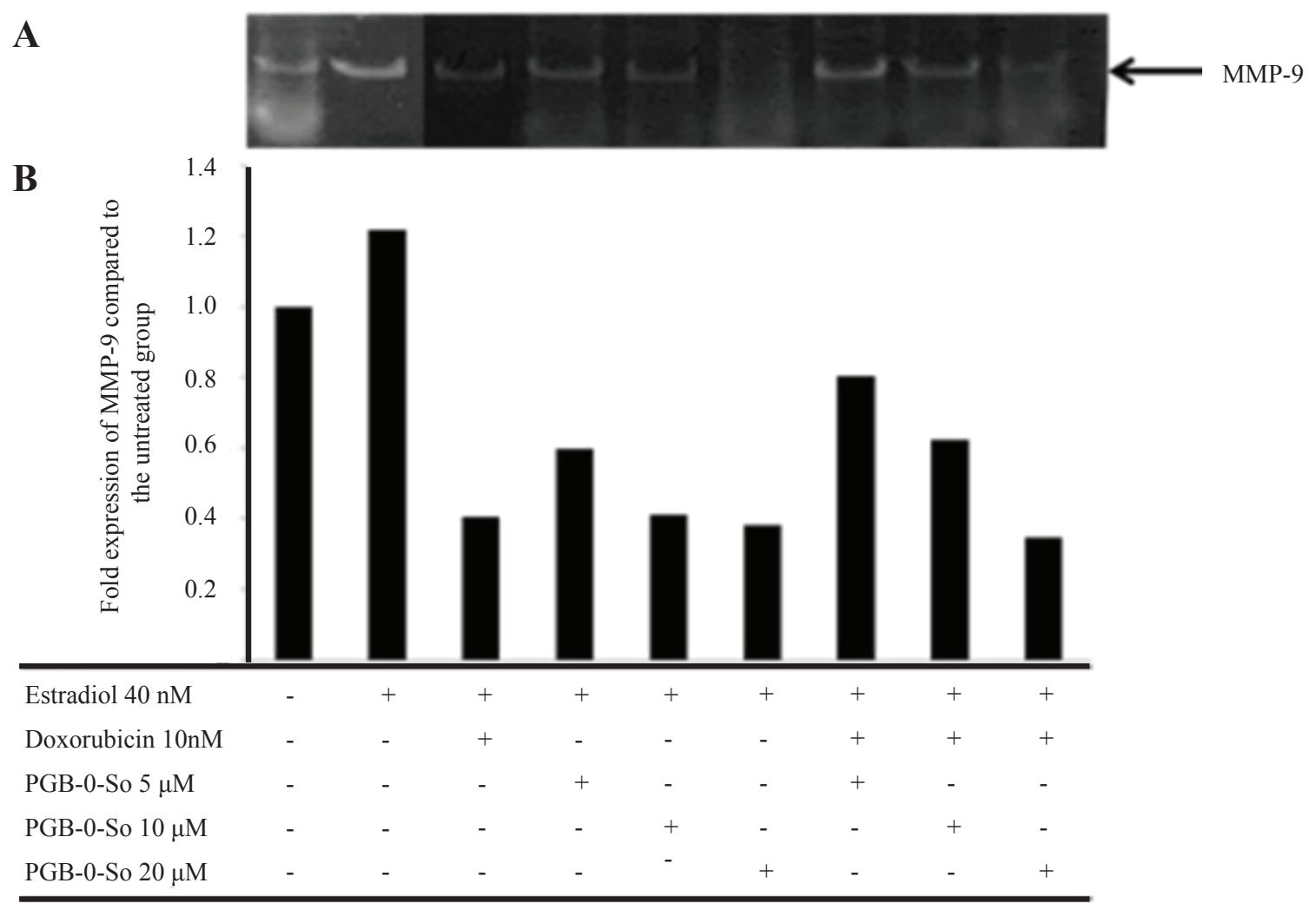

Figure 2. Result of MMP-9 Expression Following The Treatment of PGB-0-So, Doxorubicin, and PGB-0-So Combination with Doxorubicin (48 hours). A: Clear protein bands formed indicating the presence of MMP-9 protein. B: Intensity Quantification of MMP-9 band compared to the untreated groups. 
Doxorubicin is usually used as chemotherapeutic first-line treatment of several type of cancer especially triple negative breast cancer. Prolonged use of doxorubicin showed toxicity effect such as cardiotoxicity and hepatotoxicity (Pedrycz and Kramkowska, 2016). On the other hand, another research reported that doxorubicin at low dose can enhanced cancer cell migration by inducing lamellipodia formation (Amalina, et al., 2017). Previous studies showed the migration inbitory activity of PGB-0-So (Pentagamaboronon0 -sorbitol) in 4T1 cells (unpublished data). PGB-0So showed cytotoxic effect on $4 \mathrm{~T} 1$ cells with $\mathrm{IC}_{50}$ values of $39 \mu \mathrm{M}$ (unpublished data). While PGB-0 has $\mathrm{IC}_{50}$ value $300 \mu \mathrm{M}$ in $4 \mathrm{~T} 1$ cells (unpublished data), and $270 \mu \mathrm{M}$ in MCF-7/Her2 cells (Utomo, et al., 2017).

In this present study, we also observed the inhibition of cancer cell migration as the one of parts of metastasis process by treatment of PGB0 -So through scratch wound healing assay. Cell migration is part of the metastasis process. Based on the percent graph of 4T1 cell closure (Figure 1A) the treatment of PGB-0-So with concentration 5 and $10 \mu \mathrm{M}$ had demonstrated unsignificant migration inhibitory activity in all time course compared to the negative control group (untreated). On the other hand, $20 \mu \mathrm{M}$ concentration of PGB-0-So began to affect significantly the inhibition of cell migration especially after 42 nd hours.

The treatment of doxorubicin $10 \mathrm{nM}$ showed higher \% closure than untreated cells, it means that doxorubicin induced cell migration. Previous study reported that doxorubicin induced lamelipodia formation and cell migration in 4T1 and MCF-7/Her2 cells (Amalina, et al., 2017). Furthermore, combination treatment of PGB-0So and doxorubicin showed inhibition of 4T1 cell migration 42 hours after incubation time. At this incubation time both single PGB-0-So $1 / 2$ $\mathrm{IC}_{50}$ treatment and its combination with $10 \mathrm{nM}$ doxorubicin showed significant differences with the difference in closing percentages compared to the control of cells without treatment. Whereas when PGB-0-So treatment with doxorubicin $10 \mathrm{nM}$ compared with a single treatment doxorubicin 10 $\mathrm{nM}$ resulted in lower closing percentage indicating the inhibitory activity of PGB-0-So.

It has been reported in the breast cancer patients where there is a significant association between high MMP9 expression and poor survival (Song, et al., 2013) so that MMP-9 expression would be potential therapeutic agents to inhibit development of cancer metastasis. Curcumin analogue PGB-0-So showed tendency of inhibitory effect of MMP-9 activity in gelatin zymograph assay 48 hours after treatment. Previous study also showed that PGB-0 inhibited MMP-9 expression (soon will be published). Curcumin itself showed the inhibition of MMP-9 expression by inhibiting Mitogen- activated Protein Kinase (MAPK) phosphorylation (Cao, et al., 2014). Other research showed that simultaneous silencing of MMP-9 in breast cancer cells decreased the wound healing, migratory, invasive and adhesive capacity of the cells by increasing cell-cell adhesion and modulating EMT genes (Moirangthem, et al., 2016).

\section{CONCLUSION}

PGB-0-So exhibits anti-migration effect against doxorubicin treatment cells. PGB-0-So also inhibits MMP-9 activity which has role in tumor invasion.

\section{REFERENCES}

Amalina, N.D., Nurhayati, I.P., and Meiyanto, E., 2017, Doxorubicin Induces Lamellipodia Formation and Cell Migration, Indones. J. Cancer Chemoprevent., 8(2), 61-67.

Bandyopadhyay, A., Wang, L., Agyin, J., Tang, Y., Lin, S., Yeh, I.T., et al., 2010, Doxorubicin in Combination with a Small TGFB Inhibitor: A Potential Novel Therapy for Metastatic Breast Cancer in Mouse Models, PLOS ONE, 5(4), e10365.

Baribeau, S., Chaudhry, P., Parent, S., and Asselin, É, 2014, Resveratrol Inhibits Cisplatin-induced 
Epithelial-to-mesenchymal Transition in Ovarian Cancer Cell Lines, PloS ONE, 9(1), e86987.

Bhatnagar, B., Gilmore, S., Gloubeva, O., Pelser, C., Medeiros, M., Chumsri, S., et al., 2014, Chemotherapy Dose Reduction Due to Chemotherapy Induced Peripheral Neuropathy in Breast Cancer Patients Receiving Chemotherapy in The Neoadjuvantar Adjuvant Settings: A Single-center Experience, SpingerPlus, 3, 366.

Calvo, M.B., Figueroa, A., Pulido, E.G., Campelo, R.G., and Aparicio, L.A., 2010, Potential Role of Sugar Transporters in Cancer and Their Relationship with Anticancer Therapy, Int. J. Endocrinol, 2010, 1-14.

Bradke, T.M., Hall, C., Carper, S.W., and Plopper, G.E., 2008, Phenylboronic Acid Selectively Inhibits Human Prostate and Breast Cancer Cell Migration and Decreases Viability, Cell Adhes. Migr., 2(3), 153-160.

Cao, J., Han, Z., Tian, L., Chen, K., Fan, Y., Ye, B., et al., 2014, Curcumin Inhibits EMMPRIN and MMP-9 Expression Through AMPK-MAPK and PKC Signaling in PMA Induced Macrophages, J. Transl. Med., 12, 266.

Carvalho, C., Santos, R.X., Cardoso, S., Correia, S., Oliveira, P.L., Santos, M.S., et al., 2009, Doxorubicin: The Good, the Bad and the Ugly Effect, Current Med. Chem., 16(25), 3267-3286.

Chen, B.G., Zhang, M.Y., Zhao, Y.Y., Zhang, J., and Sun, C.C., 2006, Structural and Electronic Properties of BPA-fructose Complex Used in Boron Neutron Capture Therapy, J. Mol. Struct. THEOCHEM, 766, 35-40.

Da'i, M., Suhendi, A., Meiyanto, E., Jenie, U.A., and Kawaichi, M., 2017, Apoptosis Induction Effect Of Curcumin And Its Analogs Pentagamavunon-0 And Pentagamavunon-1 On Cancer Cell LINES, Asian J. Pharm. Clin. Res., 10(3), 373-376.

Dai, M., Margono, S.A., Jenie, U.A., Kawaichi, M. and Meiyanto, E, 2011, Pentagamavunon-1 Menghambat Siklus Sel T47D Terinduksi Caspase Inhibitor Z-Vad-Fmk pada Fase G2/M, Jurnal Farmasi Indonesia, 4(5), 180-187

Dawood, S., Merajver, S.D., Viens, P., Vermeulen, P.B., Swain, S.M., et al., 2010, International Expert Panel on Inflammatory Breast Cancer: Consensus Statement for Standardized Diagnosis and Treatment, Ann. Oncol., 22(3), 515-523.

de Ruijter, T.C., Veeck, J., de Hoon, J.P.J., van Engeland, M., and Tjan-Heijnen, V.C., 2011, Characteristics of Triple-negative Breast Cancer, J. Cancer Res. Clin. Oncol., 137(2), 183-192.

DuPré, S.A., Redelman, D., and Hunter, K.W., 2007, The Mouse Mammary Carcinoma 4T1: Characterization of The Cellular Landscape of Primary Tumours and Metastatic Tumour Foci, Int. J. Exp. Pathol., 88(5), 351-360.

Fan, X., Liu, H., Liu, M., Wang, Y., Qiu, L., and Cui, Y., 2017, Increased Utilization of Fructose has A Positive Effect on The Development of Breast Cancer, PeerJ, 5, e3804.

Ferlay, J., Soerjomataram, I., Ervik, M., Dikshit, R., Eser, S., and Mathers, C., 2013, GLOBOOCAN 2012 Cancer Incidence and Mortality Worldwide: IARC Cancer Base No. 11, Lyon: International Agency for Research on Cancer.

Gavilá, J., Lopez-Tarruella, S., Saura, C., Muñoz, M., Oliveira, M., De la Cruz-Merino, L., et al., 2015, SEOM Clinical Guidelines in Metastatic Breast Cancer 2015, Clin. Transl. Oncol., 17, 946-955.

Heppner, G.H., Miller, F.R., Shekhar, P.V.M., 2000, Nontransgenic Models of Breast Cancer, Breast Cancer Res, 2(5), 331-334.

Hermawan, A., Fitriasari, A., Junedi, S., Ikawati, M., Haryanti, S., Widaryanti, B., et al., 2011, PGV-0 and PGV-1 Increase Apoptosis Induction of Doxorubicin on MCF-7 Breast Cancer Cells, Pharm J Indones., 2(12), 55-59.

LaHann, T.R., Lu, D.R., Daniell, G., Sills, C., Kraft, S.L., Gavin, P.R., et al., 1993., Bioavailability of Intravenous Formulations of P-Boronophenylalanine in Dog and Rat, In: Advances in Neutron Capture Therapy, Boston: Springer, pp.585-589.

Macheda, M.L., Rogers, S., and Best, J.D., 2005, Molecular and Cellular Regulation of Glucose Transporter (GLUT) Proteins in Cancer, J. Cell. Physiol., 202(3), 654-662.

Mallesch, J.L., Moore, D.E., Allen, B.J., McCarthy, W.H., Jones, R., and Stening, W.A., 1994, The Pharmacokinetics of $\mathrm{p}$-Boronophenylalanine. Fructose in Human Patients with Glioma and Metastatic Melanoma, Int. J. Radiat. Oncol. Biol. Phys., 28, 1183-1188. 
McAuley, E.M., Bradke, T.A., and Plopper, G.E., 2011. Phenylboronic Acid is A More Potent Inhibitor Than Boric Acid of Key Signaling Networks Involved in Cancer Cell Migration, Cell Adhes. Migr., 5(5), 382-386.

Meiyanto, E., Supardjan, Dai, M., and Agustina, D, 2006, Antiproliferative Effect of Pentagamavunon- 0 on Breast Cancer Cell Line T47D, Jurnal Kedokteran YARSI, 14(1), 11-15.

Meiyanto, E., Putri, D.D., Susidarti, R.A., Murwanti, R., Sardjiman, Fitriasari, A., et al., 2014, Curcumin and Its Analogues (PGV-0 and PGV-1) Enhance Sensitivity of Resistant MCF-7 Cells to Doxorubicin Through Inhibition of HER2 and NFkB Activation, Asian Pac. J. Cancer Prev., 15(1), 179-184.

Nurulita, N.A. and Meiyanto, E. 2006. The Anticancer Effects of Pentagamavunon-0 (PGV0) to T47D Cell Line Induced by 17-B-Estradiol Through Apoptosis Induction and Angiogenesis suppression Mechanism, Sains Kesehatan, 19(1), 109- 125.

Moirangthem, A., Bondhopadhyay, B., Mukherjee, M., Bandyopadhyay, A., Mukherjee, N., Konar, K., et al., 2016, Simultaneous Knockdown of UPA and MMP9 Can Reduce Breast Cancer Progression by Increasing Cell-cell Adhesion and Modulating EMT Genes, Sci. Rep., 6, 21903.

Pedrycz, A. and Kramkowska, A., 2016. Adriamycin - Efficacy and Possible Adverse Effects, Curr. Probl. Psychiatry, 17(1), 38-46.

Pulaski, B.A. and Ostrand-Rosenberg, S., 2000, Mouse 4T1 Breast Tumor Model, Curr. Protoc. Immunol., 20, 20.2.1-20.2.16.

Putri, H., Jenie, R.I., Handayani, S., Kastian, R.F., and Meiyanto, E., 2016, Combination of Potassium Pentagamavunon-0 and Doxorubicin Induces Apoptosis and Cell Cycle Arrest and Inhibits Metastasis in Breast Cancer Cells, Asian Pac. J. Cancer Prev., 17(5), 2683-2688.
Song, J., Su, H., Zhou, Y.Y., and Guo, L.L., 2013, Prognostic Value of Matrix Metalloproteinase 9 Expression in Breast Cancer Patients: A metaanalysis, Asian Pac. J. Cancer Prev., 14(3), 1615-1621.

Thorn, C.F., Oshiro, C., Marsh, S., HernandezBoussard, T., McLeod, H. , Klein, T.T., et al. , 2011, Doxorubicin Pathways: Pharmacodynamics and Adverse Effects, Pharmacogenet. Genomics., 21(7), 440-446.

Utomo, R.Y., Putri, H., Pudjono, P., Susidarti, R.A., Jenie, R.I., and Meiyanto, E., 2017, Synthesis And Cytotoxic Activity of 2,5-Bis(4-Boronic Acid)Benzylidine Cyclopentanone nn Her2 Overexpressed-Cancer Cells, Indones. J. Pharm, 28(2), 74.

Vandooren, J., Van den Steen, P.E., and Opdenakker, G., 2013, Biochemistry and Molecular Biology of Gelatinase B or Matrix Metalloproteinase-9 (MMP-9): The Next Decade, Crit. Rev. Biochem. Mol. Biol., 48(3), 222-272.

Yabluchanskiy, A., Yonggang, M., lyer, R.P., Hall, M.E., and Lindsey, M.L., 2013, Matrix Metalloproteinase-9: Many Shades of Function in Cardiovascular Disease, Physiology, 28(6), $391-403$

Yerlikaya, A. and Erin, N, 2008, Differential Sensitivity of Breast Cancer and Melanoma Cells to Proteasome Inhibitor Velcade, Int. J. Mol. Med., 22(6), 817-823

Yoshino, K., Suzuki, A., Mori, Y., Kakihana, H., Honda, C., Mishima, Y., et al., 1989, Improvement of Solubility of p-boronophenylalanine by Complex Formation with Monosaccharides, Strahlenther. Onkol., 165(2-3), 127-129.

Zamora-León, S.P., Golde, D.W., Concha, I.I., Rivas, C.I., Delgado-López, F., Baselga, J., et al., 1996., Expression of The Fructose Transporter GLUT5 in Human Breast Cancer, Proc. Natl. Acad. Sci. USA, 93(26), 1847-1852. 